\title{
Chemical Composition of the Above-ground Biomass of Amaranthus cruentus and $A$. hypochondriacus
}

\author{
B. PÍSAŘIIKOVÁa ${ }^{\mathrm{a}}$ J. PETERKA ${ }^{\mathrm{b}}$, M. TRČKOVÁa ${ }^{\mathrm{a}}$ J. MOUDRÝ ${ }^{\mathrm{b}}, \mathrm{Z}$. ZRALÝa ${ }^{\mathrm{a}}$ I. HERZIG \\ aVeterinary Research Institute, Brno, Czech Republic \\ bUniversity of South Bohemia, Faculty of Agriculture, České Budějovice, Czech Republic \\ Received September 12, 2005 \\ Accepted March 16, 2006
}

\begin{abstract}
Písaříková B., J. Peterka, M. Trčková, J. Moudrý, Z. Zralý, I. Herzig: Chemical Composition of the Above-ground Biomass of Amaranthus cruentus and A. hypochondriacus. Acta Vet. Brno 2006, 75: 133-138.

Forty samples of dry above-ground biomass of two species and four varieties of Amaranthus cruentus (varieties Olpir, Amar 2 RR-R 150, and A 200 D) and A. hypochondriacus (variety No. 1008 ) were analyzed to determine their nutritional value during the experimental period covering five growth stages since inflorescence emergence till full ripening of grain from day 80 to day 120 of cultivation. The content of crude protein in the investigated amaranth varieties significantly decreased (from $158.2 \pm 1.20-185.4 \pm 2.33$ to $103.8 \pm 1.20-113.1 \pm 0.01 \mathrm{~g} / \mathrm{kg}$ ) as well as did the crude ash content (from $169.9 \pm 0.14-192.2 \pm 0.42$ to $129.7 \pm 0.14-138.4 \pm 0.21 \mathrm{~g} / \mathrm{kg}$ ). In contrast, the ether extract content significantly increased (from $12.2 \pm 0.14-15.9 \pm 0.28$ to $28.0 \pm 0.28-$ $36.4 \pm 0.14 \mathrm{~g} / \mathrm{kg}$ ) as well as crude fibre (from $144.9 \pm 2.12-170.0 \pm 3.68$ to $183.6 \pm 7.00-276.0$ $\pm 1.20 \mathrm{~g} / \mathrm{kg}$ ), and gross-energy (from $16.6 \pm 0.03-17.2 \pm 0.07$ to $18.1 \pm 0.14-18.4 \pm 0.01 \mathrm{MJ} / \mathrm{kg}$ ) between days 80 and 120 of cultivation. The relatively high content of crude protein in the aboveground biomass in the period between days 80 and 90 of cultivation suggests that the plants could be used as a nutrient substitute for conventional forages.
\end{abstract}

Amaranth varieties, growth stage, crude protein, ether extract, crude fibre, crude ash, nitrogenfree extractives, organic matter, gross-energy

Alternative sources of feeds offering high-quality nutrients, especially proteins, limiting amino acids but also energy, may be found in unconventional plants. The genus Amaranthus (L.) belongs to the Amaranthaceae family and includes more than 60 species (Kalač and Moudrý 2000), most of which are weeds. Under conditions of the Czech Republic, three grain species Amaranthus cruentus, A. hypochondriacus, and A. caudatus are of importance. The plants are characterized by a great diversity of species and forms, and green parts of some species are used as vegetable. In the Czech Republic the cultivation of amaranth was introduced in the early 1990s (Michalová 1999; Moudrý et al. 1999). Environmental requirements and technological conditions under which the plant can be grown are already well known.

Selected genotypes of A. cruentus (varieties Olpir, Amar 2 RR-R150, and A 200 D) and A. hypochondriacus (variety No. 1008) are characterized by early maturity, lower demands for temperature during germination, fast growth after germination, and early establishment of canopy. The plants are readily adaptable to soil and climatic conditions (Michalová 1998; Jarošová et al. 1997). Experience obtained up to now with its cultivation has shown that field yields range from 0.6 to $2.4 \mathrm{t} / \mathrm{ha}$. However, preconditions for yield increase of amaranth grain exist (Jarošová et al. 1997). The possibilities of growing amaranth under Czech conditions have been studied by Michalová (1998), Moudrý et al. (1998), Jarošová and Moudrý (1999), Peterka et al. (1999).

The grain of the current amaranth species has a high nutritional value. The dry matter of the grain is $90-94 \%$ (Andras ofs zky et al. 1998), crude protein ranges from 15 to $18 \%$,

\footnotetext{
Address for correspondence:

Ing. Bohumila Písaříková

Veterinary Research Institute

Hudcova 70, 62132 Brno

Czech Republic
}

Phone: +420 533331616

Fax:+420 541211229

E-mail address: pisarikova@vri.cz

http://www.vfu.cz/acta-vet/actavet.htm 
ether extract (fat) from 6 to $8 \%$, crude fibre from 3 to $5 \%$, ash from 2 to $3 \%$, and nitrogenfree extractives from 60 to $65 \%$ (Carlss on 1979; Bressani et al. 1987; Bressani and Liggoria 1994; Szelenyi-Galantai and Zsolnai-Harszi 1992).

The advantage of amaranth grains compared to conventional cereals is a relatively high content of proteins and a more balanced amino acid composition (Kalač and Moudrý 2000). The amaranth grain is rich in lysine, tryptophan and sulphur amino acids. A suitable content of lysine and tryptophan together with a low content of leucine makes it a highquality supplement for e.g. maize, which is rich in leucine but poor in lysine and tryptophan (Vetter 1994). The relatively high lipid content in the amaranth grain is connected with a favorable composition of fatty acids. Grain lipids are rich in linoleic and palmitic acids (Lorenz and Hwang 1985); the presence of squalene is a specific factor that can be used in human medicine. Moreover, isolated squalene has been used in computers.

The nutritional value of the above-ground biomass depends on the growth stages of plants. The contents of crude protein were $29.5,22.7$, and $16.3 \%$, those of crude fibre were 11.1 , 14.3 , and $17.0 \%$, and the yield was $19.7,154.3$, and $510.7 \mathrm{~kg} /$ ha at the harvest 25,45 and 60 days after planting, respectively, as reported by Alfaro et al. (1987). Crude fat content ranged from 2.0 to $3.0 \%$, crude fibre from 11.1 to $24.4 \%$, and ash from 13.1 to $17.8 \%$ in dry matter of the above-ground biomass of amaranth according to the data in literature (Alfaro et al. 1987; Škultéty et al. 1991; Zeman et al. 1995).

The aim of our study was to determine the dependence of chemical composition and grossenergy in the above-ground biomass of four different genotypes in two amaranth species $(A$. cruentus and A. hypochondriacus) on the growth stage between days 80 and 120 .

\section{Materials and Methods}

Samples of the dry above-ground biomass of two species and four varieties of amaranth: A. cruentus (varieties Olpir, Amar 2 RR-R 150, and A 200D) and A. hypochondriacus (variety No. 1008) were analyzed to determine their nutritional value ( 40 samples have been taken from 4 cultivars, 10 samples per cultivar, 5 harvest times, 2 samples per harvest time per cultivar). The plants were grown in experimental fields in 1999, and the seeds were sown on May 13. Plant density was 36 plants per $\mathrm{m}^{2}$. When the plants were $15 \mathrm{~cm}$ high, nitrogen fertilizer $(27.5 \%$ calcium ammonium nitrate, $\mathrm{CaNH}_{4} \mathrm{NO}_{3}$ ) was added at the dose of $50 \mathrm{~kg} \mathrm{~N} / \mathrm{ha}$. The plants were harvested on September 20 when they were ripe for cutting. Samples collected during the growing season were analyzed for the dynamics of changes in selected variables of nutritional value.

Growth stages (DC) in selected varieties in 1999

\begin{tabular}{|lccccccc|}
\hline Days of cultivation & 57 & 68 & 78 & 89 & 99 & 109 & 120 \\
\hline Olpir & $24-30$ & 30 & $30-39$ & 40 & $61-68$ & $70-80$ & 90 \\
Amar 2 RR-150 & $24-30$ & 30 & $30-39$ & 40 & $61-68-70$ & $80-90$ & 90 \\
A 200 D & $24-30$ & 30 & $30-39$ & 40 & $61-68$ & $70-80$ & 90 \\
No. 1008 & $24-30$ & 30 & $30-39$ & 40 & $61-68$ & $70-80$ & 90 \\
\hline
\end{tabular}

Samples of the above-ground biomass were collected on days $80,90,100,110$, and 120 of cultivation. According to a macrophenological assessment of growth stages, the following stages can be observed: from day 80 - a rapid elongation and stem branching, and the inflorescence emergence; from day 90 - an apex formation in the main panicle, the onset of flowering; from day 100 - the anthesis, pollination, and the onset of seed formation; from day 110 - the milk and dough development of seeds; and from day 120 the full ripening of seeds (Jarošo vá et al. 1997). Samples were taken at representative quantities (A non y mous 2001). After harvesting, the plants were spread and dried at room temperature.

Treatment of samples for chemical analyses was carried out in accordance with the Czech Standards (An ony mous 1996). Dry matter, crude protein, ether extract, crude fibre, and crude ash were established in two parallel samples using the standard methods for laboratory testing of feeds published in the AOAC (2001). Calorimetry was used to determine gross-energy (Kacerovský et al. 1990). The values of nitrogen-free extractives and organic matter were calculated. The final results are presented in dry matter so that comparisons 
could be made. Statistical characteristics were obtained using the program Stat Plus (Matoušková et al. 1992). The dependence of chemical composition on the plant growth stage was established using linear regression and regression coefficients $(\mathrm{r})$.

\section{Results and Discussion}

The composition of all plants throughout the growing season changes, and therefore the feeding value and digestibility change, too. There is a high content of crude protein in young plants but this gradually decreases. By comparison, the content of nitrogen-free substances, especially that of fibre, increases (Nehring 1955). Chemical composition, gross-energy, and regression coefficients of the above-ground biomass in the variety Olpir, Amar 2 RR-R 150, A $200 \mathrm{D}$ and No. 1008 are presented in Tables 1, 2, 3, and 4. During the investigated period from day 80 to day 120 of cultivation, the content of crude protein linearly decreased: in Olpir from 170.2 to $103.8 \mathrm{~g} / \mathrm{kg}(p<0.05)$ (Table 1), in Amar 2 RR-R 150 from 158.2 to $110.2 \mathrm{~g} / \mathrm{kg}(p<0.05)$ (Table 2), in A $200 \mathrm{D}$ from 185.4 to $108.9 \mathrm{~g} / \mathrm{kg}$ (Table 3 ) and in No. 1008 from 183.6 to $113.1 \mathrm{~g} / \mathrm{kg}$ (Table 4).

Table 1. Chemical composition ( $\mathrm{g} / \mathrm{kg}$ ), gross-energy $(\mathrm{MJ} / \mathrm{kg})$ in dry matter of Amaranthus cruentus, variety Olpir in dependence on growth stage

\begin{tabular}{|lrrrrr|rr|}
\hline $\begin{array}{l}\text { Days of } \\
\text { cultivation }\end{array}$ & \multicolumn{1}{c}{80} & \multicolumn{1}{c}{90} & \multicolumn{1}{c}{100} & \multicolumn{1}{c|}{110} & \multicolumn{1}{c|}{120} & $\mathrm{r}$ \\
\hline Crude protein $^{1}$ & $170.2 \pm 4.60$ & $161.9 \pm 3.54$ & $122.4 \pm 2.40$ & $122.2 \pm 2.26$ & $103.8 \pm 1.20$ & -0.9565 & $*$ \\
Ether extract & $13.9 \pm 0.21$ & $19.3 \pm 0.42$ & $29.0 \pm 0.78$ & $32.1 \pm 0.21$ & $33.4 \pm 0.21$ & 0.9599 & $*$ \\
Crude fibre & $138.0 \pm 2.97$ & $168.6 \pm 3.32$ & $184.2 \pm 3.89$ & $200.8 \pm 2.19$ & $206.3 \pm 7.21$ & 0.9689 & $*$ \\
Crude ash & $192.2 \pm 0.42$ & $158.7 \pm 0.14$ & $139.7 \pm 1.56$ & $138.4 \pm 0.07$ & $137.5 \pm 0.85$ & -0.8746 & $\mathrm{NS}$ \\
Nitrogen-free & & & & & & & \\
extractives & $485.7 \pm 2.05$ & $491.5 \pm 1.85$ & $524.7 \pm 2.16$ & $506.5 \pm 1.20$ & $519.0 \pm 2.40$ & 0.7643 & $\mathrm{NS}$ \\
Organic matter & $807.8 \pm 0.50$ & $841.3 \pm 0.20$ & $860.3 \pm 1.80$ & $861.6 \pm 0.15$ & $862.5 \pm 1.60$ & 0.8746 & $\mathrm{NS}$ \\
Gross energy & $16.8 \pm 0.05$ & $17.8 \pm 0.04$ & $18.1 \pm 0.02$ & $18.2 \pm 0.42$ & $18.3 \pm 0.11$ & 0.8802 & $\mathrm{NS}$ \\
\hline
\end{tabular}

${ }^{1}(\mathrm{~N} \times 6.25), \quad \mathrm{r}=$ regression coefficient, $\quad$ significance of linear regression* $p<0.05, * * p<0.01$ $\mathrm{NS}=$ non-significant

Table 2. Chemical composition ( $\mathrm{g} / \mathrm{kg})$, gross-energy $(\mathrm{MJ} / \mathrm{kg})$ in dry matter of Amaranthus cruentus, variety Amar 2 RR-R 150 in dependence on growth stage

\begin{tabular}{|lrrrrr|rc|}
\hline $\begin{array}{l}\text { Days of } \\
\text { cultivation }\end{array}$ & \multicolumn{1}{c}{80} & \multicolumn{2}{c}{90} & \multicolumn{1}{c}{100} & \multicolumn{1}{c}{110} & \multicolumn{1}{c|}{120} & \multicolumn{1}{c|}{ r } \\
\hline Crude protein & $158.2 \pm 1.20$ & $144.4 \pm 2.97$ & $118.8 \pm 1.77$ & $112.3 \pm 1.84$ & $110.2 \pm 2.47$ & -0.9480 & $*$ \\
Ether extract & $12.2 \pm 0.14$ & $16.1 \pm 0.28$ & $18.6 \pm 0.07$ & $24.1 \pm 0.21$ & $28.0 \pm 0.28$ & 0.9943 & $* *$ \\
Crude fibre & $144.9 \pm 2.12$ & $189.0 \pm 5.69$ & $219.6 \pm 5.51$ & $243.6 \pm 2.12$ & $276.0 \pm 1.20$ & 0.9944 & $* *$ \\
Crude ash & $169.9 \pm 0.14$ & $161.6 \pm 0.50$ & $149.2 \pm 0.57$ & $146.9 \pm 0.14$ & $134.0 \pm 0.42$ & -0.9858 & $* *$ \\
Nitrogen-free & & & & & & & \\
extractives & $514.8 \pm 1.41$ & $488.9 \pm 2.36$ & $493.8 \pm 1.98$ & $473.1 \pm 1.13$ & $451.8 \pm 1.08$ & -0.9510 & $*$ \\
Organic matter & $830.1 \pm 0.20$ & $838.4 \pm 0.55$ & $850.8 \pm 0.63$ & $853.1 \pm 0.31$ & $866.0 \pm 0.40$ & 0.9858 & $* *$ \\
Gross-energy & $16.6 \pm 0.03$ & $17.4 \pm 0.01$ & $17.8 \pm 0.23$ & $18.0 \pm 0.04$ & $18.1 \pm 0.14$ & 0.9333 & $*$ \\
\hline
\end{tabular}

${ }^{1}(\mathrm{~N} \times 6.25), \quad \mathrm{r}=$ regression coefficient,$\quad$ significance of linear regression $* p<0.05, * * p<0.01$ $\mathrm{NS}=$ non-significant

The content of crude ash linearly decreased: in Olpir from 192.2 to $137.5 \mathrm{~g} / \mathrm{kg}$ (Table 1$)$, in Amar 2 RR-R 150 from 169.9 to $134.0 \mathrm{~g} / \mathrm{kg}(p<0.01)$ (Table 2), in A $200 \mathrm{D}$ from 182.7 to $129.7 \mathrm{~g} / \mathrm{kg}(p<0.01)$ (Table 3), and in No. 1008 from 192.2 to $138.4 \mathrm{~g} / \mathrm{kg}$ (Table 4). In contrast, the contents of crude fibre linearly increased: in Olpir from 138.0 to $206.3 \mathrm{~g} / \mathrm{kg}$ 
Table 3. Chemical composition $(\mathrm{g} / \mathrm{kg})$, gross-energy $(\mathrm{MJ} / \mathrm{kg})$ in dry matter of Amaranthus cruentus, variety A $200 \mathrm{D}$ in dependence on growth stage

\begin{tabular}{|lrrrrr|rr|}
\hline $\begin{array}{l}\text { Days of } \\
\text { cultivation }\end{array}$ & \multicolumn{1}{c}{80} & \multicolumn{1}{c}{90} & \multicolumn{1}{c|}{100} & \multicolumn{1}{c|}{110} & \multicolumn{1}{c|}{120} & \multicolumn{1}{c|}{$\mathrm{r}$} & \\
\hline Crude protein & $185.4 \pm 2.33$ & $149.9 \pm 3.68$ & $114.9 \pm 2.05$ & $110.0 \pm 2.83$ & $108.9 \pm 0.63$ & -0.9129 & $\mathrm{NS}$ \\
Ether extract & $15.9 \pm 0.28$ & $18.6 \pm 0.21$ & $26.5 \pm 0.21$ & $33.4 \pm 0.42$ & $36.4 \pm 0.14$ & 0.9867 & $* *$ \\
Crude fibre & $170.0 \pm 3.68$ & $173.3 \pm 3.68$ & $177.9 \pm 3.75$ & $181.5 \pm 3.96$ & $183.6 \pm 7.00$ & 0.9935 & $* *$ \\
Crude ash & $182.7 \pm 0.14$ & $159.7 \pm 0.14$ & $150.8 \pm 0.35$ & $142.4 \pm 0.07$ & $129.7 \pm 0.14$ & -0.9787 & $* *$ \\
$\begin{array}{l}\text { Nitrogen-free } \\
\text { extractives }\end{array}$ & $446.0 \pm 1.61$ & $498.5 \pm 1.93$ & $530.8 \pm 1.59$ & $532.7 \pm 1.80$ & $541.4 \pm 1.90$ & 0.9064 & NS \\
Organic matter & $817.3 \pm 0.21$ & $840.3 \pm 0.20$ & $849.2 \pm 0.40$ & $857.6 \pm 0.19$ & $870.3 \pm 0.20$ & 0.9787 & $* *$ \\
Gross-energy & $17.0 \pm 0.07$ & $17.6 \pm 0.17$ & $17.9 \pm 0.01$ & $17.9 \pm 0.01$ & $18.4 \pm 0.01$ & 0.9558 & $*$ \\
\hline
\end{tabular}

${ }^{1}(\mathrm{~N} \times 6.25), \quad \mathrm{r}=$ regression coefficient, $\quad$ significance of linear regression $* p<0.05, * * p<0.01$ $\mathrm{NS}=$ non-significant

Table 4. Chemical composition (g/kg), gross-energy $(\mathrm{MJ} / \mathrm{kg})$ in dry matter of Amaranthus hypochondriacus, variety No. 1008 in dependence on growth stage

\begin{tabular}{|lrrrrr|c|c|}
\hline $\begin{array}{l}\text { Days of } \\
\text { cultivation }\end{array}$ & \multicolumn{1}{c}{80} & \multicolumn{1}{c}{90} & \multicolumn{1}{c}{100} & \multicolumn{1}{c|}{110} & \multicolumn{1}{c|}{120} & $\mathrm{r}$ \\
\hline Crude protein $^{1}$ & $183.6 \pm 1.41$ & $150.0 \pm 0.64$ & $117.6 \pm 1.27$ & $117.2 \pm 1.63$ & $113.1 \pm 0.01$ & -0.9063 & $\mathrm{NS}$ \\
Ether extract & $14.8 \pm 0.49$ & $17.6 \pm 0.35$ & $28.7 \pm 0.78$ & $29.6 \pm 0.28$ & $33.2 \pm 0.01$ & 0.9559 & $*$ \\
Crude fibre & $163.5 \pm 3.39$ & $173.5 \pm 3.60$ & $196.6 \pm 7.71$ & $196.7 \pm 7.70$ & $233.7 \pm 5.23$ & 0.9552 & $*$ \\
Crude ash & $192.2 \pm 0.50$ & $158.1 \pm 0.28$ & $141.7 \pm 1.34$ & $141.4 \pm 0.85$ & $138.4 \pm 0.21$ & -0.8727 & NS \\
Nitrogen-free & & & & & & & \\
extractives & $445.9 \pm 1.45$ & $500.8 \pm 1.22$ & $515.4 \pm 2.75$ & $515.1 \pm 1.40$ & $481.6 \pm 1.08$ & 0.4653 & NS \\
Organic matter & $807.8 \pm 0.60$ & $841.9 \pm 0.34$ & $858.3 \pm 0.40$ & $858.6 \pm 0.98$ & $861.6 \pm 0.36$ & 0.8727 & NS \\
Gross-energy & $17.2 \pm 0.07$ & $17.6 \pm 0.17$ & $18.0 \pm 0.07$ & $18.1 \pm 0.01$ & $18.4 \pm 0.01$ & 0.9821 & $* *$ \\
\hline
\end{tabular}

${ }^{1}(\mathrm{~N} \times 6.25), \quad \mathrm{r}=$ regression coefficient,$\quad$ significance of linear regression $* p<0.05, * * p<0.01$ $\mathrm{NS}=$ non-significant

$(p<0.05)$ (Table 1), in Amar 2 RR-R 150 from 144.9 to $276.0 \mathrm{~g} / \mathrm{kg}(p<0.01)$ (Table 2), in A $200 \mathrm{D}$ from 170.0 to $183.6 \mathrm{~g} / \mathrm{kg}(p<0.01)$ (Table 3), and in No. 1008 from 163.5 to 233.7 $\mathrm{g} / \mathrm{kg}(p<0.05)$ (Table 4).

The content of ether extract linearly increased: in Olpir from 13.9 to $33.4 \mathrm{~g} / \mathrm{kg}(p<0.05)$ (Table 1), in Amar 2 RR-R 150 from 12.2 to $28.0 \mathrm{~g} / \mathrm{kg}(p<0.01)$ (Table 2), in A $200 \mathrm{D}$ from 15.9 to $36.4 \mathrm{~g} / \mathrm{kg}(p<0.01)$ (Table 3$)$, and in No. 1008 from 14.8 to $33.2 \mathrm{~g} / \mathrm{kg}(p<0.05)$ (Table 4); and there was a corresponding increase of gross-energy: in Olpir from 16.8 to 18.3 $\mathrm{MJ} / \mathrm{kg}$ (Table 1), in Amar 2 RR-R 150 from 16.6 to $18.1 \mathrm{MJ} / \mathrm{kg}(p<0.05)$ (Table 2), in A $200 \mathrm{D}$ from 17.0 to $18.4 \mathrm{MJ} / \mathrm{kg}(p<0.05)$ (Table 3), and in No. 1008 from 17.2 to $18.4 \mathrm{MJ} / \mathrm{kg}$ $(p<0.01)$ (Table 4$)$.

The values of nitrogen-free extractives ranged in Olpir from 485.7 to $524.7 \mathrm{~g} / \mathrm{kg}$ (Table 1), in Amar 2 RR-R 150 the values linearly decreased from 514.8 to $451.8 \mathrm{~g} / \mathrm{kg}(p<0.01)$ (Table 2), in A $200 \mathrm{D}$ nitrogen-free extractives ranged from 446.0 to $541.4 \mathrm{~g} / \mathrm{kg}$ (Table 3 ), and in No. 1008 from 445.9 to $515.4 \mathrm{~g} / \mathrm{kg}$ (Table 4). The content of organic matter linearly increased, Olpir from 807.8 to $862.5 \mathrm{~g} / \mathrm{kg}$ (Table 1), Amar 2 RR-R 150 from 830.1 to $866.0 \mathrm{~g} / \mathrm{kg}(p<0.01)$ (Table 2), A $200 \mathrm{D}$ from 817.3 to $870.3 \mathrm{~g} / \mathrm{kg}(p<0.01)$ (Table 3) and No. 1008 from 807.8 to $861.6 \mathrm{~g} / \mathrm{kg}$ (Table 4).

The above mentioned data correspond with those obtained by Alfaro et al. (1987) who reported that in A. hypochondriacus green matter on day 25 after planting the content of 
crude protein was $29.5 \%$, and that of crude fibre was $11.1 \%$; on day 40 the content of crude protein was $22.7 \%$ and the crude fibre content increased to $14.3 \%$; on day 60 the protein content was the lowest (14.4\%) and the crude fibre content was $17.0 \%$.

Pond and Lehmann (1989) reported the following values in the dried biomass of the Zimbabwe cultivar PI 482049 of $A$. cruentus, which was harvested 1 week after anthesis: dry matter $94.0 \%$, crude ash $18.4 \%$, cell contents $64.3 \%$, NDF $33.7 \%$, ADF $24.0 \%$, ADL $5.2 \%$, crude protein $(\mathrm{N} \times 6.25) 16.2 \%$, compared to the first cutting lucerne hay, when the following values were obtained: dry matter $87.2 \%$, cell contents $40.5 \%$, NDF $59.5 \%$, ADF $47.1 \%$, cellulose $38.1 \%$, ADL $10.0 \%$, crude protein $(\mathrm{N} \times 6.25) 13.6 \%$.

The recorded content of crude protein in A. hypochondriacus No.1008 was higher compared to the level mentioned by Riveros and Cristi (1988) in A. cruentus (20.6 $9.7 \%$ ) from the start of vegetative growth to the harvest time.

The chemical composition of amaranth suggests difficult ensiling. Škultéty et al. (1991) investigated in bulls the digestibility of green, dried and ensilaged amaranth A. hypochondriacus No. 1008, whose crude protein ranged from 25.3 to $15.7 \%$, depending on the growth stage at harvest. A very low ensilage digestibility was observed, suggesting its low quality.

\section{Conclusions}

The obtained results showed a significant dependence of nutritional value of the aboveground biomass of amaranth on the plant growth stage. During plant growth, the nutritional value decreased, which was presented especially by a significant linear decrease of the crude protein content and a significant increase of crude fibre. From the viewpoint of the crude protein content and satisfactory production of the above-ground biomass at the same time, the period from day 80 to 90 of cultivation, i.e. the inflorescence emergence and onset of flowering, appears as the most suitable for harvest. Of the four variants under investigation, A $200 \mathrm{D}$ (A. cruentus) and No. 1008 (A. hypochondriacus) proved to be better sources of nutrients, having higher protein content. This relatively high content of crude protein shows that the above-ground biomass of amaranth can be used as a nutrient substitute for conventional forages in the form of dry biomass.

\section{Nutriční hodnota sušené nadzemní biomasy amarantu - Amaranthus cruentus a A. hypochondriacus}

Ke zjištění živinového složení bylo analyzováno 40 vzorků suché nadzemní biomasy rostlin dvou druhů a čtyř odrůd amarantu: A. cruentus (Olpir, Amar 2 RR-R 150, A 200 D) a A. hypochondriacus (No. 1008). Během pěti růstových fází od stadia nasazování květu do plné zralosti zrna mezi 80. a 120. dnem vegetace u sledovaných odrůd signifikantně poklesl obsah dusíkatých látek (ze 158,2 $\pm 1,20$ až 185,4 $\pm 2,33 \mathrm{~g} / \mathrm{kg}$ na 103,8 $\pm 1,20$ až $113,1 \pm 0,01$ $\mathrm{g} / \mathrm{kg}$ ) a obsah popela (ze 169,9 $\pm 0,14$ až $192,2 \pm 0,42 \mathrm{~g} / \mathrm{kg}$ na $129,7 \pm 0,14$ až $138,4 \pm 0,21$ $\mathrm{g} / \mathrm{kg}$ ). Naopak signifikantně narůstal obsah tuku (z 12,2 $\pm 0,14$ až $15,9 \pm 0,28 \mathrm{~g} / \mathrm{kg}$ na 28,0 $\pm 0,28$ až $36,4 \pm 0,14 \mathrm{~g} / \mathrm{kg}$ ), vlákniny (ze $144,9 \pm 2,12$ až $170,0 \pm 3,68 \mathrm{~g} / \mathrm{kg}$ na $183,6 \pm 7,00$ až $276,0 \pm 1,20 \mathrm{~g} / \mathrm{kg}$ ) a brutto energie (z 16,6 $\pm 0,03$ až $17,2 \pm 0.07 \mathrm{MJ} / \mathrm{kg}$ na $18,1 \pm 0,14 \mathrm{až}$ $18,4 \pm 0,01 \mathrm{MJ} / \mathrm{kg}$ ) mezi 80. a 120 . dnem vegetace. Relativně vysoký obsah živin nadzemní biomasy amarantu v období od 80 . do 90 . dne vegetace predeterminuje možnost jejího využití k náhradě konvenčních krmiv.

Acknowledgments

The study was supported by the NAZV of Ministry of Agriculture of the Czech Republic (Project No. 3112) MSM 6007665806 and Grant MZe No. 0002716201. 


\section{References}

ALFARO MA, MARTINEZ A, RAMIREZ R, BRESSANI R 1987: Yield and chemical composition of the vegetal parts of the amaranth (Amaranthus hypochondriacus L.) at different physiological stages. Arch Latinoam Nutr 37: 108-121

ANDRASOFSZKY E, SZÖCZ Z, FEKETE S, JELENITS K 1998: Evaluation of the nutritional value of the amaranth plant. I. Raw and heat-treated grain tested in experiments on growing rats. Acta Vet Hung 46: 47-59

ANONYMOUS: Notice No. 194/1996, Annex 3, Ministry of Agriculture of the Czech Republic (in Czech)

ANONYMOUS: Notice No. 124/2001, Annex 2, Ministry of Agriculture of the Czech Republic (in Czech)

AOAC - Association of Official Analytical Chemists International, 2001: Official Methods of Analysis. 17th ed. Horwitz W. (Ed.): AOAC Inc., Arlington, USA

BRESSANI R, GONZALES JM, ZUNIGA J, BREUNER M, ELIAS LG 1987: Yield of amaranth grain representing four species. J Sci Food Afric 38: 347-356

BRESSANI R, LIGORRIA LE 1994: Effect of lime cooking of grain amaranth oil selected chemical-components and one its protein-quality. J Agric Chem 42: 1998-2001

CARLSSON R 1979: Quantity and quality of Amaranthus from plants in temperate, cold and hot and subtropical climates - a review. In: Proc. of Second Amaranth Conference, Rodale, Emmaus, Pennsylvania, USA. ISBN/ISSN 0878573275, 48-58

JAROŠOVÁ J, MOUDRÝ J 1999: Evaluation of production abilities of selected amaranth genotypes cultivated in conditions of Czech Republic. In: Proc. of 4th European Symposium of Amaranth, Nitra, Slovak Republic. ISBN 80-7139-054-2, 38-42

JAROŠOVÁ J, MICHALOVÁ A, VAVREINOVÁ S, MOUDRÝ J 1997: Cultivation and use of amaranth. Metodiky pro zemědělskou praxi, ISBN 80-7271-042-7, 37 p. (in Czech)

KACEROVSKÝ O, BABIČKA L, BÍRO D, HEGER J, JEDLIČKA Z 1990: Testing and assessment of feedstuffs. SZN Praha, 216 p. (in Czech)

KALAČ P, MOUDRÝ J 2000: Chemical composition and nutritional value of amaranth grains (in Czech). Czech J Food Sci 18: 201-206

LORENZ K, HWANG YS 1985: Lipids in amaranths. Nutr Rep Int 31: 83-89

MATOUŠKOVÁ O, CHALUPA J, CÍGLER M, HRUŠKA K 1992: STAT Plus - user's guide. Veterinary Research Institute Brno, 168 p. (in Czech)

MICHALOVÁ A 1998: Variability of selected characters in the sets of buckwheat, millet and amaranth; selection of prospective genotypes and comparison of their nutritional values (in Czech). In: Proc. of International Conference ,Triticale and other non-traditional cereals“. Nitra, Slovak Republic. ISBN-80-967538-9-4, 89-99

MICHALOVÁ A 1999: Amaranthus L. Vyz Potrav 54: 13-14 (in Czech)

MOUDRÝ J, PEJCHA J, PETERKA J 1999: The effect of genotype and farming technology on the yield of amaranth Amaranthus sp. Collection of Scientific Papers, Faculty of Agriculture in České Budějovice, Series for Crop Sciences 16: 93-98 (in Czech)

MOUDRÝ J, VAVREINOVÁ S, JAROŠOVÁ J 1998: Production of Amaranthus in the Czech Republic. In: Proc. of 16th International Conference „Cereal science - its contribution to health and well being“. Vienna, Austria, $17 \mathrm{p}$.

NEHRING K 1955: Animal nutrition and feed science. SVPL Bratislava, 460 p. (in Slovak)

PETERKA J, PEJCHA J, MOUDRÝ J 1999: Production of amaranth biomass. In: Proceeding of 4th European Symposium of Amaranth, Nitra, Slovak Republic, ISBN 80-7139-054-2, 53-55

POND WG, LEHMANN WG 1989: Nutritive value of a vegetable amaranth cultivar for growing lambs. J Anim Sci 67: 3036-3039

RIVEROS E, CRISTI A 1988: Amaranth as a new source for animal feeding. In: Proc. VI World Conf on Anim Prod, WAAP-88 Helsinki, 352 p.

ŠKULTÉTY M, ŠKULTÉTYOVÂ N, BENCOVÁ E 1991: Intake of dry matter and digestibility of nutrients from green ensilaged and pelleted amaranth Amaranthus hypochondriacus variety 1008. Živoč Výr 36: 793-798 (in Slovak)

SZELENYI-GALANTAI M, ZSOLNAI-HARSZI I 1992: Chemical and biological investigation of some seeds of the amaranth species and improvement of their protein utilization by supplementation of maize and wheat. Allattenyesztes es Takarmanyorzas 41: 337-348 (in Hungarian)

VETTER J 1994: Minerals and amino acids in the seeds of the new, cultivated „cereal-like“ species Amaranthus hypochondriacus. Z Lebensm Unters Forsch 198: 284-286

ZEMAN L, ŠIMEČEK K, KRÁSA A, ŠIMEK M, LOSSMANN J 1995: The tables for nutritional values of feeds. VUVZ Pohořelice, ISBN 80-901598-3-4, 465 p. (in Czech) 